\title{
APEC Moves Behind-the-Border: Evidence that Structural Reform Will Hasten Income Convergence in the Asia-Pacific Region
}

\author{
Robert A. Buckle* and Amy A. Cruickshank**1
}

\begin{abstract}
This paper provides empirical estimates of the impact of domestic regulations and structural policies on income convergence in APEC economies since 1989. It is concluded that structural policies can reduce the 'half-life' of complete income convergence from about a century to a matter of a single generation. It also analyses the recent shift in focus of $A P E C$ to place greater emphasis on structural policies in promoting regional economic integration.
\end{abstract}

\section{The Evolution of APEC Priorities}

The promotion of sustainable economic growth and improved living standards in the Asia-Pacific region through enhanced trade and economic integration lies at the heart of APEC's mission. ${ }^{2}$ Although significant tariff peaks still exist in some areas in APEC, such as food and primary production, significant progress in tariff reduction in the APEC region has been achieved (average tariffs have decreased from 16.6 per cent in 1988 to 6.4 per cent in 2004). ${ }^{3}$ While APEC's focus has traditionally been on trade and investment liberalisation, it has more recently turned its attention also to the role played by 'behind-the-border' policies in enabling or impeding regional economic integration, also commonly referred to as 'structural policies' or 'structural barriers'. 4

In 2004 APEC Leaders recognised that structural reform is essential for realising the full benefits of trade and investment liberalisation and achieving sustainable improvements in living standards by endorsing the Leaders' Agenda

\footnotetext{
1 *Victoria University of Wellington, bob.buckle@vuw.ac.nz; ${ }^{* *}$ The Treasury, New Zealand. The views expressed in this paper are those of the authors and do not necessarily reflect the views of The Treasury. 2 Founded in 1989, APEC (Asia Pacific Economic Cooperation) is a grouping of 'economies' on the Asia-Pacific Rim. It currently has 21 members: Australia; Brunei Darussalam; Canada; Chile; People's Republic of China; Hong Kong, China; Republic of Indonesia; Japan; Republic of Korea; Malaysia; Mexico; New Zealand; Papua New Guinea; Peru; Republic of the Philippines; Russia; Singapore; Thailand; Chinese Taipei; United States; and Viet Nam.

${ }^{3}$ In 1996, in all countries except Australia and New Zealand, MFN average applied tariffs for agriculture are higher than for the whole economy (OECD 2001).

${ }^{4}$ Behind-the-border policies refer to domestic measures which enable or impede the efficient operation of markets and the capacity of businesses to operate. These can take the shape of domestic regulatory systems, competition frameworks, and governance structures.
} 
to Implement Structural Reform (LAISR). There was an increased emphasis on LAISR in Australia's 2007 host year. ${ }^{5}$ During 2007, the mode of operations of the APEC Economic Committee was reformed to focus on the five LAISR priority areas and to inject greater impetus to structural reform in the region. In August 2008 Australia hosted the first APEC ministerial meeting wholly dedicated to structural reform. The $16^{\text {th }}$ APEC Leaders' Summit, held in Lima on 23 November, strongly endorsed structural reform. ${ }^{6}$

This paper provides empirical evidence for the strong impact structural policies can have on income convergence of APEC economies.

Section 2 of the paper reviews the theoretical and empirical literature on economic growth and income convergence, and the role of structural policies in impeding or promoting growth and convergence. ${ }^{7}$ Estimates of income convergence amongst APEC economies and the effect on income convergence of structural policies are presented in section 3. Section 4 reviews APEC's role in promoting improved structural policies in the Asia-Pacific region. Concluding remarks are provided in section 5.

\section{Economic Growth and Income Convergence in the Asia-Pacific Region}

Economic growth models provide a framework for thinking about how economic growth processes and income convergence take place, and how behind-the-border policy settings can influence the process. Traditional and modern economic growth theories suggest that we would expect to find lower-income economies growing faster than higher-income economies, thereby bringing about the convergence of per-capita incomes between economies over time.

Convergence in the neoclassical growth model is driven by capital flowing from places where it is abundant (high-income economies) to where it is scarce (low-income economies) to achieve the highest possible returns. In this way, economic integration can bring about growth and income convergence. However, empirical evidence suggests that capital flows from high-income to low-income economies are very modest and much less than predicted by the neoclassical growth model (Lucas 1990). Migration, trade and specialisation are other mechanisms that could drive growth and income convergence (see Sinn 2007; Frankel and Romer 1999).

\footnotetext{
${ }^{5}$ This was foreshadowed by a preliminary conference in December 2006 on 'Reshaping APEC for the Asia-Pacific Century: Priorities and Strategies'. The program and papers prepared for the APEC Study Centre Network Preliminary Conference are available here: http://www.apec.org.au/event2.asp? event=40. 6 The 2008 APEC Leaders' Declaration is available from http://www.apec.org/apec/leaders_declarations/2008.html

7 A fuller discussion of economic growth and income convergence mechanisms is provided in Buckle and Cruickshank (2007).
} 
Endogenous growth models emphasise the spill-over of ideas and technological knowledge as a key mechanism driving growth and income convergence. The transfer of scientific knowledge may occur through foreign direct investment (FDI) in low-income economies, bringing with it the skills of investors, or through international trade. Economies may 'learn by exporting' through interacting with foreign customers and learning how to meet higher product standards, or through technology embodied in imports. Keller (2004) surveys the literature on the extent of international technology diffusion and the channels through which technology is spread. He concludes that there is no evidence that international learning is inevitable, or that it is easier for relatively undeveloped economies. Evidence suggests that importing is associated with technological spill-overs, but evidence of benefits associated with exporting is weaker. The literature suggests that there can be spill-overs from FDI but they vary between economies, regions, sectors, and firm structures. Similar conclusions are drawn in the surveys by Greenaway and Kneller (2007) and Wagner (2007).

In addition to 'static gains' from trade (arising from economies exploiting their comparative advantage and economies of scale), there are also potential 'dynamic gains' from trade. Dynamic gains from trade refer to trade-related improvements in an economy's productivity growth rate that arise from increased integration in the global economy. A recent OECD (2007) study identified three interconnected channels through which trade may increase productivity: by increasing investment; aiding technological diffusion; and promoting the competitive impetus to innovate. The empirical evidence on dynamic gains from trade is mixed. Research has not established a robust link between trade policy and long-run productivity growth rates. However, there is a strong correlation between increasing shares of trade in gross domestic product (GDP) and GDP growth.

Traditional and modern growth theories imply that there are potential benefits from 'economic openness' for all economies, not simply the lower-income economies, through specialisation, better allocation of skills and other resources, the dynamic interaction of learning, and the two-way spill-over of knowledge. Outward-orientation and strong growth performances have resulted in impressive economic growth in some low-income economies in the APEC region in recent years. Notable examples include China and Vietnam and, earlier, Korea and Singapore. However, progress across the APEC region has been patchy and evidence suggests that convergence mechanisms may not be operating as well as expected in some economies due to barriers at and behind the border. Furthermore, recent thinking suggests that what it takes to achieve growth at lower income levels may be different from what it takes to sustain growth at higher levels of income, and over the long term (World Bank 2007a; Rodrik 2003; Gill and Kharas 2007). This raises the question of not only how to lift performance in the slower-growing economies but also whether, and how, the 
recent impressive growth performances of some economies in the region can be sustained in the future.

Results from growth regressions suggest that deregulation in countries that start from a position of heavy regulation will result in improved economic performance. Djankov et al. (2005) found, after controlling for other factors, that economies with better regulations, as measured by the World Bank's Ease of Doing Business indicator, grow faster. In particular, they concluded that improving from the worst quartile of business regulations to the best implies a 2.3 per cent increase in annual GDP growth. Improving from the worst quartile to the third quartile implies a 1.1 per cent increase in annual GDP growth. Erickson (2006) updated this work using the 2006 Ease of Doing Business data and an expanded sample of economies. Erickson was not able to reject the basic message of Djankov et al. that economies with better regulations grow faster, although his estimates of the gains were smaller (concluding that economies would achieve a 1.4 per cent growth increase from moving from the worst quartile to the best, and 0.6 per cent increase from moving from the worst quartile to the third quartile).

Alesina et al. (2005) show that the effect of product-market deregulation in OECD countries since the 1970s had significant effects on investment in utilities, transport and communications. By using indices of product-market regulation and by estimating the effects of these regulations on the rate of growth catch-up at the industry level in OECD economies, Nicoletti and Scarpetta (2003) show that product-market regulation tended to slow down catch-up growth in manufacturing and services. Their evidence also suggests that entry-limiting regulation may hinder the adoption of new technologies, possibly by reducing competitive pressures, technology spill-overs, or the entry of new high-technology firms.

Using a different approach, which captures general equilibrium adjustments and links various economies in the region, Dee (2005) evaluates the economic payoffs from structural policy reform in the East Asian region. This study includes nine APEC economies: China, Japan, Korea, Indonesia, Malaysia, Philippines, Singapore, Thailand and Australia. Dee examines the impact of three scenarios: a regional preferential trade agreement (including trade liberalisation and the elimination of regulations that discriminate against foreigners); the successful completion of the Doha round of World Trade Organisation (WTO) negotiations; and unilateral regulatory reform. Dee's estimates show that preferential trade liberalisation and preferential reform of regulations would add US $\$ 16.6$ billion per annum and US $\$ 2$ billion per annum respectively to regional income. The successful completion of the Doha round would result in much larger gains of over US\$30 billion per annum. However, by far the largest 
gains result from unilateral regulatory reform, which is estimated to result in gains of over US\$100 billion per annum for the region.

On a cautionary note, the studies referred to in this section do need to be treated with some care given the difficulties in quantifying the extent of domestic regulatory restrictiveness, and hence measuring the gains from reforming. However, reviews of the evidence, such as the paper by Crafts (2006), suggest that the quality of regulation can impact significantly on productivity growth. Crafts also reviews other evidence of the effects of regulations on productivity and growth, including the transmission channels, and concludes that there is solid evidence that product-market regulation reduces productivity growth, particularly through creating barriers to entry, and this is more damaging in the context of new technological opportunities.

This review of international evidence suggests that in order to promote regional economic integration and productivity growth, it is appropriate that APEC promotes sound microeconomic structural policies, in addition to its traditional focus on trade and investment policies, and macroeconomic and financial policies. This is also supported by insights from the experiences of economies that have undertaken comprehensive or even partial structural reforms that suggest policy coherence is important. Policy coherence is achieved when economic policies support, or at least do not undermine, the effectiveness of other policies in attaining overall policy objectives, such as improved economic performance and higher standards of living. For example, openness to trade and FDI leads to opportunities, not guarantees, which may not be realised if structural policies do not support competition and efficiency. Similarly, gains from structural reforms increase significantly in an economy that can leverage global opportunities (APEC Policy Support Unit 2008).

Chile's pro-competitive reform is an example of how policy can be designed to enhance the beneficial effects of trade policy reform. During the period after the late 1970s, Chile gradually removed high import tariffs and moved toward a low-level uniform import tariff (Corbo 1997). In order to avoid the negative impact of a uniform tariff on domestic competition, from the 1990s Chile introduced a more liberal investment regime and started to negotiate preferential trade agreements (PTAs) with many trade partners in a strategy of 'additive regionalism', thus allowing a significant number of foreign firms to fully compete with domestic producers.

In the next section we undertake a simple test of whether structural policies impact on income convergence in APEC economies by estimating a standard cross-economy convergence model for the region using a method along the lines of Baumol (1986) and Barro (1991). 


\section{Testing Income Convergence amongst APEC Economies}

If incomes of APEC economies were converging we would expect to see a negative correlation between initial income levels and the subsequent growth rate of incomes, since low-income economies would be growing faster than high-income economies. Figure 1 plots the real average per-capita income level of APEC economies in 1989 against the real average annual growth rate of per-capita income for the period 1989 to 2007. The figure is suggestive of convergence in the region. However, progress is patchy and there is a cluster of economies with low initial incomes that are not 'catching up'.

Figure 1: Convergence of APEC economies' incomes, 1989-2007

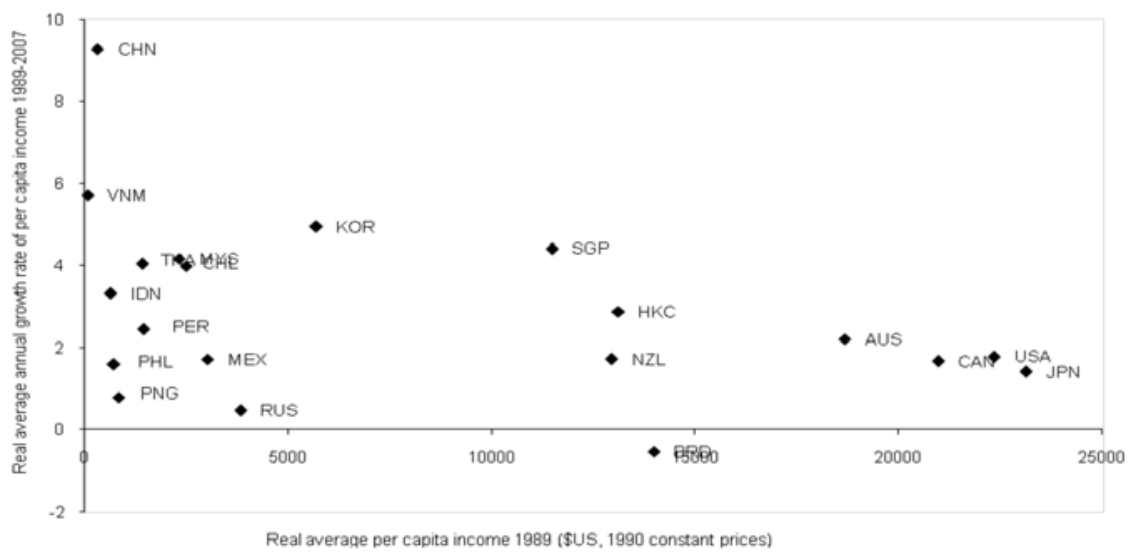

Source: United Nations Statistical Database.

Note: Excludes Russia for period 1990-2007 due to data gaps. Excludes Chinese Taipei due to data gaps.

The diversity of APEC economies, in terms of their income and productivity levels, recent economic growth, and business environments, means it is an interesting case to evaluate income convergence issues. Some low-income economies in the APEC region are growing rapidly (such as China and Vietnam), some moderately (such as Mexico and Peru), and some quite slowly (such as PNG and the Philippines), despite marked reductions in tariffs across the region. The business and economic environment also varies markedly across the region. As shown in Figure 2, the ranking of APEC economies in cross-country studies of the business and economic environment ranges from first to fifty-first out of 55 economies in terms of economic competitiveness and first to one-hundred-and-fortieth out of 181 economies in the ease of doing business (World Competitiveness Online 2008; World Bank Ease of Doing Business Database 2009). 
Figure 2: Ease of doing business, and world competitiveness indices, APEC economies

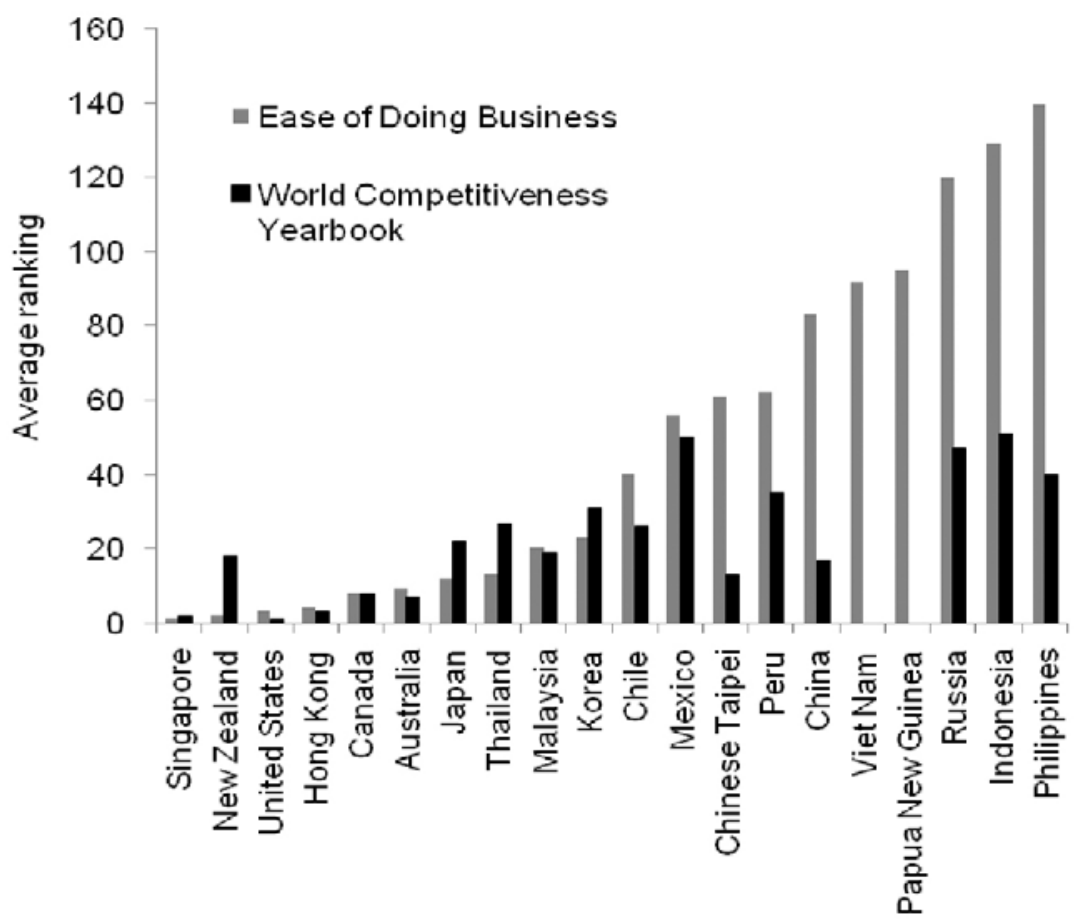

Source: Ease of Doing Business Database, World Bank 2009; and World Competitiveness Online, IMD Business School 2008.

It is possible to test empirically whether convergence is occurring in the APEC region, irrespective of economies' structural policies. Per-capita income convergence is a property derived from the neoclassical growth model. Letting $y^{s}$ denote the steady state level of per-capita income and $y(t)$ the level of per-capita income at time $t$, the growth rate of per-capita income around the steady state can be approximated by the following differential equation:

$$
\frac{d \ln (y(t))}{d t}=\beta\left[\ln \left(y^{s}\right)-\ln (y(t))\right]
$$

where $\beta>0$.

This equation states that the further away an economy is from its steady-state level of per-capita income the faster its growth rate of per-capita income, where $\beta$ measures the speed of convergence to the steady state. This is known as unconditional $\beta$-convergence - the property that poor economies will tend to grow faster than rich economies that have the same steady-state level of per-capita income. Equation (1) implies that: 


$$
\ln (y(t))=\left(1-e^{-\beta t}\right) \ln \left(y^{s}\right)+e^{-\beta t} \ln (y(0))
$$

where $y(0)$ is income per capita in the initial period. Subtracting $\ln (y(0))$ from both sides of equation (2) yields:

$$
\ln (y(t))-\ln (y(0))=\left(1-e^{-\beta t}\right) \ln \left(y^{s}\right)-\left(1-e^{-\beta t}\right) \ln (y(0))
$$

Based on equation (3), various researchers have estimated the following cross-economy regression:

$$
\frac{1}{t} \ln \left[\frac{y(t)_{i}}{y(0)_{i}}\right]=a+b \ln (y(0))+\varepsilon_{\text {a }}
$$

where $\frac{1}{t} \ln \left[\frac{y(t)_{i}}{y(0)_{i}}\right]$ is economy $i$ between time 0 and $t, y(0)_{i}$ is the level of per-capita income in time 0 , and $\hat{b}=-\frac{\left(1-e^{-\beta t}\right)}{t}$. Regression (4) is an approximation and has the limitation that if extrapolated over a long time period, per-capita incomes will eventually begin diverging as countries with low initial incomes and higher annual growth rates overtake countries with higher initial incomes.

If per-capita income convergence (often described as 'catch-up') was occurring, then we would expect to see a negative relationship between initial per-capita income levels and subsequent growth rates (that is, we would expect the $b$ coefficient in regression (4) to be negative). There is some debate in the literature about whether it is appropriate to weight observations according to the size of the economy (that is, to place greater weight on China than Chile). Since we are interested in convergence between economies with different policy settings, we have given equal weight to each of the cross-sectional observations in this paper.

The results of regression (4) are summarised in columns (a) to (d) of Table 1. Looking at the 16 years prior to the formation of APEC (1972-88), there is no evidence of per-capita income convergence in APEC or the rest of the world. However, in the period since APEC was formed in 1989, there is evidence of convergence in the APEC region. The estimates suggest that the annual average rate of convergence in the APEC region over the period 1989-2007 is 0.73 per cent. $^{8}$ This means that the estimated 'half-life' (the time taken to close half of the gap between income levels of high- and low-income economies) for APEC is

\footnotetext{
${ }^{8}$ From (3) and (4), the annual rate of convergence is calculated as follows: ${ }^{\hat{b}=-\frac{\left(1-e^{-\beta t}\right)}{t}}$, therefore $\beta=-\frac{\ln (1+\hat{b} t)}{t}$.
} 
96 years. These results are based on real per-capita incomes expressed in US dollars from the United Nations Statistic Database. If per-capita income is measured in purchasing power parity (PPP) terms (to account for differences in the relative prices of goods and services in different economies) then the estimated speed of convergence is slightly faster. For the period 1989-2007, the annual average rate of convergence in the APEC region (for the 18 APEC economies for which data are available) is 0.85 per cent. This means that the estimated half-life is 81 years. $^{9}$

While there has been convergence on average of per-capita income levels of APEC economies, Figure 1 indicates that the process is characterised by some low-income economies achieving very high growth, some merely matching the growth of higher-income economies, and some economies falling behind. The theoretical literature and previous empirical studies suggest that differences in structural policies between countries could go some way toward explaining these differences in economic performance.

It is possible to test empirically whether economies are not catching up because of poor structural policies by estimating a conditional convergence model that controls for the quality of the economies' structural policy settings. ${ }^{10}$ As mentioned previously, cross-country rankings of the business environment and competitiveness provide an indicator of the quality of structural policies. The World Bank's Ease of Doing Business (EoDB) study endeavours to capture the direct costs of doing business (for example, costs of opening a business, accessing finance, and so on). The World Competitiveness Yearbook (WCY) is a comprehensive measure and takes into account 'economic performance' (for example, international trade and investment), 'government efficiency' (for example, fiscal policy), 'business efficiency' (for example, labour market policy) and 'infrastructure'. We present results that use both the EoDB and WCY rankings. The cross-economy regression model is: ${ }^{11}$

$$
\frac{1}{t} \ln \left(\frac{y(t)_{i}}{y(0)_{i}}\right)=a+b \ln (y(0))+c S P+\varepsilon_{i} \text {, }
$$

\footnotetext{
${ }^{9}$ The GNI per-capita purchasing power parity (PPP) data come from the World Development Indicators Database. The sample of 18 economies excludes Russia, Brunei Darussalam and Chinese Taipei due to data gaps.

${ }^{10}$ Another approach would be to look at the relationship between structural policy settings and economic growth performance, irrespective of initial income levels. Since higher-income economies tend to have better rankings on average in studies of the business environment than lower-income economies, and also tend to grow slower on average (as we would expect from convergence models), then we find no statistically significant relationship for APEC economies between structural policy settings on their own and economic growth.

11 An alternative to this model to test whether economies are not catching up because of poor structural policies would be to regress the residuals from regression (1) on the measure of structural policies; however, we believe specification (2) is more appropriate because we consider that initial income and structural policies are likely to be jointly determined.
} 
where $S P$ is a measure of the quality of structural policies for each economy (here we use economies' rankings in the EoDB Survey and the WCY as a proxy for the quality of structural policies). $S P$ is the average ranking in these indexes for the years in which data are available. ${ }^{12}$

The results of regression (5) are summarised in columns (e) to (g) in Table 1. There is evidence that structural policies seem to explain why some economies are not catching up. Economies with poor structural policies (proxied by high rankings in the cross-country measures of business competitiveness) tend to have lower annual growth rates on average. Also notice that when convergence is conditional on structural policy settings there is stronger evidence of income convergence. Using a narrower measure of the quality of structural policies, the Ease of Doing Business Index, the average annual rate of convergence is 1.57 per cent relative to 0.73 per cent in the unconditional convergence model. Using a broader measure of the quality of structural policies, the World Competitiveness Yearbook, the annual average rate of convergence is slightly higher at 1.74 per cent. $^{13}$

Since the two measures of the quality of structural policies pick up different aspects of the business and economic environment, including both measures in the regression produces stronger results. While multi-collinearity may be a problem in this regression since the two measures of structural policies are quite highly correlated, the F-statistic suggests that overall they improve the fit of the model (at five per cent level of significance). ${ }^{14}$

These results suggest that structural policies can reduce the half-life of complete income convergence from about a century to a matter of a single generation. To test how confident that we can be in the half-life computations, we compute a 95 per cent confidence interval, and find that the results based on the unconditional convergence regression (d) are quite variable. We can be 95 per cent confident that the time to close half of the gap between the income levels of high- and low-income economies is between 50 to 563 years; whereas we can be much more confident in the results from the regression that controls for structural policies (regression g). When convergence is conditional on structural policy settings, we can be 95 per cent confident that the time to close

\footnotetext{
12 Russia and Chinese Taipei are excluded from all regressions due to data gaps. WCY rankings are available for 2004-08, and include APEC economies except for Brunei Darussalam, PNG, and Vietnam. Consistent EoDB rankings are available for 2008-09 and include APEC economies except for Brunei Darussalam.

13 The results in columns (e) to $(\mathrm{g})$ of Table 1 use a smaller sample size than the results presented in column (d) since the WCY and EoDB Study do not cover all of the economies included in the sample for regression 1 . However, running regression 1 with the smaller sample of economies gives you a similar result regarding income convergence - an annual average rate of convergence of 0.849 per cent (15 economies) and 0.63 per cent ( 18 economies).

${ }^{14}$ The partial correlation coefficient between the WCY rankings and the EoDB rankings for the 15 APEC economies in the sample is 0.75 .
} 
half of the gap between the income levels of high- and low-income economies is between 19 to 59 years.

Table 1: Per capita income convergence: 1972-88 and 1989-2007

\begin{tabular}{|c|c|c|c|c|c|c|c|}
\hline & \multicolumn{2}{|c|}{$1972-88$} & \multicolumn{5}{|c|}{ 1989-2007 } \\
\hline & $\begin{array}{c}\text { (a) } \\
\text { World }\end{array}$ & $\begin{array}{c}\text { (b) } \\
\text { APEC }\end{array}$ & $\begin{array}{c}\text { (c) } \\
\text { World }\end{array}$ & $\begin{array}{c}\text { (d) } \\
\text { APEC }\end{array}$ & $\begin{array}{c}\text { (e) } \\
\text { APEC }\end{array}$ & $\begin{array}{c}\text { (f) } \\
\text { APEC }\end{array}$ & $\begin{array}{c}\text { (g) } \\
\text { APEC }\end{array}$ \\
\hline Initial GDP & $\begin{array}{c}0.0003 \\
(0.8488)\end{array}$ & $\begin{array}{l}-0.0044 \\
(0.1542)\end{array}$ & $\begin{array}{l}-0.0007 \\
(0.6781)\end{array}$ & $\begin{array}{l}-0.0068 \\
(0.0198)\end{array}$ & $\begin{array}{l}-0.0138 \\
(0.0037)\end{array}$ & $\begin{array}{l}-0.0153 \\
(0.0005)\end{array}$ & $\begin{array}{l}-0.0193 \\
(0.0004)\end{array}$ \\
\hline $\begin{array}{l}\text { Structural policies } \\
\text { (WCY) }\end{array}$ & - & - & - & - & - & $\begin{array}{l}-0.0010 \\
(0.0064)\end{array}$ & $\begin{array}{l}-0.0007 \\
(0.0338)\end{array}$ \\
\hline $\begin{array}{l}\text { Structural policies } \\
\text { (EoDB) }\end{array}$ & - & - & - & - & $\begin{array}{l}-0.0003 \\
(0.0316)\end{array}$ & - & $\begin{array}{l}-0.0002 \\
(0.1272)\end{array}$ \\
\hline $\begin{array}{l}\text { Annual average } \\
\text { rate of } \\
\text { convergence }\end{array}$ & - & - & - & $\begin{array}{l}0.73 \text { per } \\
\text { cent }\end{array}$ & $\begin{array}{l}1.58 \text { per } \\
\text { cent }\end{array}$ & $\begin{array}{l}1.74 \text { per } \\
\text { cent }\end{array}$ & $\begin{array}{c}2.28 \text { per } \\
\text { cent }\end{array}$ \\
\hline Half-life & - & - & - & 96 years & 44 years & 40 years & 30 years \\
\hline $\begin{array}{l}\text { 95per cent } \mathrm{Cl} \text { of } \\
\text { half-life }\end{array}$ & & & & $\begin{array}{c}50 \text { to } 563 \\
\text { years }\end{array}$ & $\begin{array}{c}24 \text { to } 128 \\
\text { years }\end{array}$ & $\begin{array}{c}29 \text { to } 79 \\
\text { years }\end{array}$ & $\begin{array}{c}19 \text { to } 59 \\
\text { years }\end{array}$ \\
\hline F statistic & & & & & & & $9.3975^{15}$ \\
\hline Adjusted $\mathrm{R}^{2}$ & -0.0061 & 0.0637 & -0.0052 & 0.2376 & 0.3791 & 0.5915 & 0.6428 \\
\hline $\begin{array}{l}\text { Sample } \\
\text { cross-section }\end{array}$ & 161 & 19 & 161 & 19 & 18 & 15 & 15 \\
\hline
\end{tabular}

Note: Probability values are in parentheses. Regression results presented in columns (a) and (c) include economies from the rest of the world, excluding APEC economies, where data are available for the period 1972-2007 from the United Nations Statistical Database. As a result of data gaps, regression results in columns (b), (d), and (e)-(g) exclude Russia and Chinese Taipei; columns (f) and (g) exclude Brunei Darussalam, Peru, PNG and Vietnam; and column (e) excludes Brunei Darussalam.

\section{Role of APEC in Encouraging Structural Change}

The review of international evidence in Section 2 and the results presented in Section 3 suggest that, in order to promote regional economic integration and productivity growth, it is appropriate that APEC promotes sound microeconomic structural policies, in addition to its traditional focus on trade and investment policies and its somewhat more recent focus on macroeconomic and financial policies.

The linkages between the three mutually reinforcing elements of trade and investment policies, structural policies, and macroeconomic and financial policies are depicted in Figure 3. This figure represents the mandates of APEC's three main policy committees: the APEC Committee on Trade and Investment (CTI), the Economic Committee (EC), and the Finance Ministers' Process (FMP). The greater emphasis that APEC is now placing on structural policies, coordinated and led by the Economic Committee, provides it with a more coherent economic policy agenda. 


\section{Figure 3: Three elements of APEC's economic agenda}

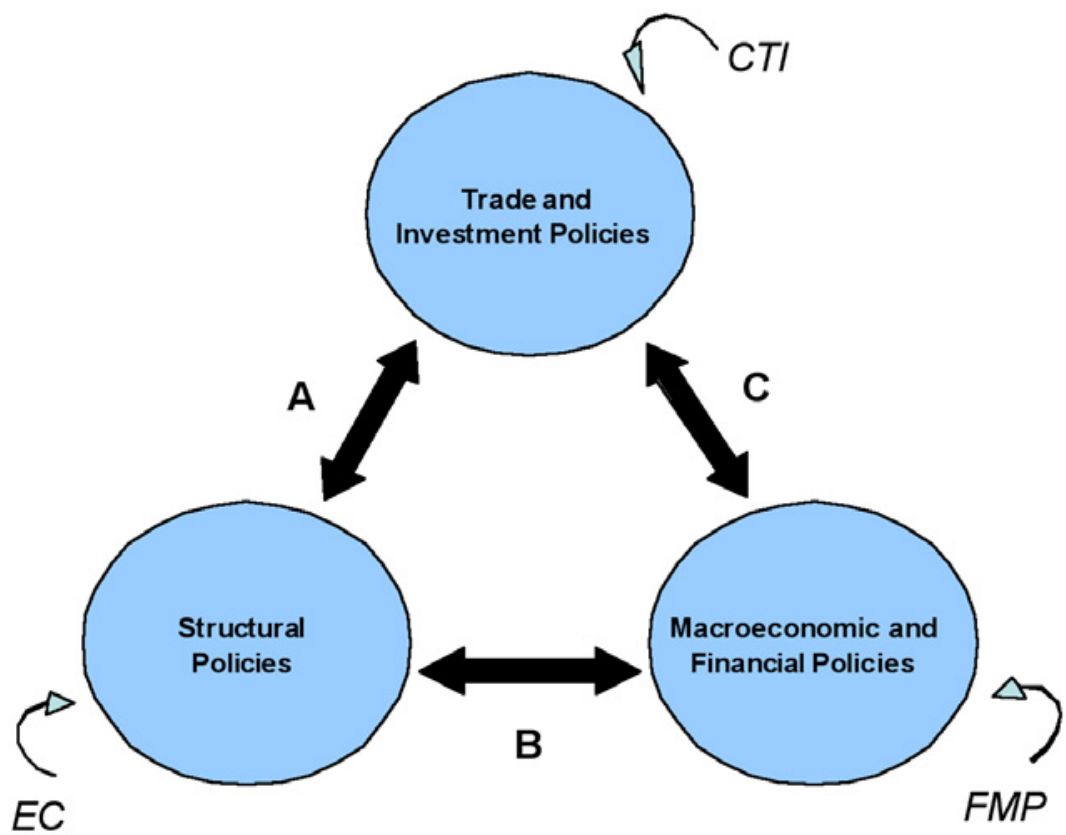

APEC provides Australia, New Zealand and other member economies with a forum to pursue measures promoting a stronger, more integrated and flexible regional economy. From the perspective of Australia and New Zealand, APEC has the additional advantage of including a number of economies that are economically important to them.

There are a number of other international and regional organisations that promote structural policy change, such as the Organisation for Economic Cooperation and Development (OECD) and the World Bank. APEC aims to draw on the work of these other organisations, but it also 'adds value' in a number of ways. ${ }^{15}$ APEC's cooperative, voluntary and informal manner of operations means that it is a good place to discuss economic policy challenges facing the Asia-Pacific region in an informal and non-adversarial environment. APEC promotes structural reform by providing a forum for senior officials across the region to discuss economic policy challenges, share experiences, build capability, and discuss good practices.

\footnotetext{
15 APEC draws on the work of other organisations by, for example, collaboratively developing tools such as the 'APEC-OECD Integrated Checklist on Regulatory Reform', by inviting participation from the OECD and World Bank in APEC seminars and workshops, by drawing on the research these organisations have undertaken (such as the World Bank's EoDB indicators), and contracting research work from specialists from these organisations.
} 
As mentioned previously, one of the interesting features of APEC is that it is a grouping of economies with quite different characteristics, and at different stages of development. While this raises some challenges, it also means that there is considerable scope for the sharing and learning from each others' experiences. Since cooperation which leads to mutual benefit does not require negotiation, APEC can contribute to improvements in members' domestic policies by fostering meaningful dialogue on structural policy issues. APEC also has a unique linkage to perspectives from the business community through the APEC Business Advisory Council (ABAC).

While the benefits of structural policy change are becoming increasingly clear, reforms often involve quite fundamental changes to how markets operate, and so can face resistance from groups that have a vested interest in the status quo. Reform can also involve transitional dislocations. Hence there are potentially significant social and political tensions and challenges involved in undertaking structural reform. APEC's approach to promoting structural policy reform has three main dimensions: policy dialogue, capacity building and awareness raising. These are each explained in turn below.

Structural policy reforms can be supported by discussing and drawing on examples of good practices from other economies. APEC facilitates the discussion and sharing of experiences through holding policy discussions, workshops and seminars, and developing good practice guidance in areas such as regulation, competition policy and corporate governance. For example, in February 2008 APEC held the first ever high-level one-day policy dialogue amongst APEC senior officials on structural reform. The EC also holds regular information-sharing discussions at its meetings styled on OECD roundtable discussions; recent examples include discussions on how to balance accountability and innovation in the public sector, and the attributes of a robust regulatory reform framework.

Economies need the financial resources and technical expertise to drive structural change. There are several ways this can be achieved. For example, the World Development Report (World Bank 2005) suggests that economies may wish to start strengthening capacity by improving the expertise of the civil service and the quality of information available to guide and administer reforms. It also highlights the importance of economies improving processes for ongoing learning from within economies and from the experiences of other economies. APEC provides a forum for economies to learn from each others' experiences, and holds regular workshops and training courses to build capacity to support structural reform; recent examples include workshops held by the EC in 2008 on e-governance, and government performance and results management.

For reforms to be successful, it is important that the costs and benefits of policy approaches are well communicated and understood by key stakeholders. Practical steps suggested by the World Development Report (World Bank 2005) 
to improve communications include raising public awareness about structural reform, mobilising a broader range of support, and maintaining momentum by, for example, establishing institutions to sustain the reform progress. APEC helps communicate the costs and benefits of policy approaches and keep structural reform issues at the fore. One way it does this is through its annual publication to APEC Leaders, the APEC Economic Policy Report. ${ }^{16}$

\section{Conclusion}

APEC's focus has shifted recently to place greater emphasis on behind-the-border structural policies in promoting regional economic integration, in addition to APEC's traditional focus on at-the-border trade and investment liberalisation and facilitation, and macroeconomic and financial policies. International research and country reform experiences, such as in Australia, Chile and New Zealand, suggest that policy coherence is an important ingredient to the success of economic reforms. Results presented in this paper suggest that behind-the-border policy settings, including the quality of regulations and costs of doing business, impact on the rate of economic growth convergence in the APEC region. We conclude therefore that $\mathrm{APEC}^{\prime} \mathrm{s}$ recent emphasis on improving the quality of behind-the-border policies, most notably through the work of APEC's Economic Committee and the implementation of LAISR, complements APEC's traditional emphasis on trade and financial policy issues and provides a more coherent economic agenda and a more coherent approach to its goals of regional economic integration and economic growth.

\section{References}

Alesina, A., Ardagna, S., Nicoletti, G. and Schiantarelli, F. 2005, 'Regulation and investment', Journal of the European Economic Association 3: 791-825.

APEC 2004, 'Leaders' Agenda to Implement Structural Reform (LAISR)' at: http://www.apec.org/apec/documents_reports/annual_ministerial_meetings/ 2004.html

APEC Economic Committee 2007, 'APEC Economic Policy Report 2007' at: http://www.apec.org/apec/apec_groups/economic_committee.html

APEC Policy Support Unit 2008, 'The Links between Trade, Investment and Structural Reform'. Background paper for APEC Structural Reform Ministerial Meeting, 3-5 August 2008.

Barro, R. J. 1991, 'Economic growth in a cross section of countries', The Quarterly Journal of Economics 106(2): 407-43.

\footnotetext{
16 The APEC Economic Policy Report is available from:

http://www.apec.org/apec/apec_groups/economic_committee.html
} 
Baumol, W. J. 1986, 'Productivity growth, convergence, and welfare: What the long-run data show', The American Economic Review 76(5): 1072-85.

Buckle, R. A. and Cruickshank, A. A. 2007, 'The challenge of structural change in APEC economies', Treasury Working Paper 07/06. http://www.treasury.govt.nz/publications/research-policy/wp/2007/07-06/

Corbo, V. 1997, 'Trade reform and uniform import tariffs: The Chilean experience', American Economic Review: Papers and Proceedings 87(2): 73-7.

Crafts, N. 2006, 'Regulation and productivity performance', Oxford Review of Economic Policy 22(2): 186-202.

Dee, P. 2005, 'East Asian trade strategies and their impact', paper presented to the CSIS/ANU Conference, Bogor, 1-2 August.

Djankov, S., McLiesh, C. and Ramalho, R. 2005, 'Regulation and growth', World Bank at: http://rru.worldbank.org/documents/discussions/ regulationofgrowth.pdf

Erickson, D. 2006, 'Testing the effect of business regulations on growth' at: http://economics.wustl.edu/conference/Honors/David_Erickson_Thesis.pdf

Frankel, J. A. and Romer, D. 1999, 'Does trade cause growth?', The American Economic Review 89(3): 379-99.

Gill, I. S. and Kharas, H. 2007, 'Back in the fast lane', Finance and Development 44(1).

Greenaway, D., and Kneller, R. 2007, 'Firm heterogeneity, exporting and foreign direct investment', The Economic Journal 117(517): 134-61.

Keller, W. 2004, 'International technology diffusion', Journal of Economic Literature 42(3): 752-82.

Lucas, R. E. 1990, 'Why doesn't capital flow from rich to poor countries?' American Economic Review 80: 92-6.

IMD Business School 2007, World Competitiveness Yearbook at: http://www.imd.ch/research/centers/wcc/index.cfm

Nicoletti, G. and Scarpetta, S. 2003, 'Regulation, productivity and growth', Economic Policy 36: 9-72.

Nordas, H., Miroudot, S. and Kowalski, P. 2006, 'Dynamic gains from trade', OECD Trade Policy Working Paper No.43.

OECD 2001, 'The Uruguay round agreement on agriculture' at: http://www.oecd.org/dataoecd/50/55/1912374.pdf

OECD 2007, 'The interaction amongst trade, investment and competition policies', Working Party of the Trade Committee. 
Rodrik, D. 2003, 'Growth strategies', NBER Working Paper No 10050, October: 19 and 39. At http://www.nber.org/papers/w10050

Sinn, H-W. 2007, 'The welfare state and the forces of globalization', NBER Working Paper No 12946, March.

Wagner, J. 2007, 'Exports and productivity: A survey of the evidence from firm level data', The World Economy 30(1): 60-82.

World Bank 2005, 'World development report: A better investment climate for everyone' at: http://siteresources.worldbank.org/INTWDR2005/ Resources/complete_report.pdf

World Bank 2007a, '10 years after the crisis, special focus: Sustainable development in east Asia's urban fringe', East Asia and Pacific Update.

World Bank 2007b, Ease of Doing Business Database at: http://www.doingbusiness.org/ExploreEconomies/?economyid=140 